\title{
Hearing about your diagnosis while walking on the beach
}

Michael Wynn, DO

Neurology ${ }^{\circledR} 2019 ; 93: 80$. doi:10.1212/WNL.0000000000007758

Waning moon,

a defiance of brown pelicans

skimming sheet metal waves,

salted cedar perfusing

this August evening-

each perfect in its indifference.

Molecules move from feather to leaf, leaf to bone, bone to beach. Relentless as the letters we did not write.

This sand absorbs my sorrow without limit.

Darkness

always finds light. Light

moves through darkness

with defiant agency.

Like our faith in each other,

like a tidepool-

vibrant, immortal.
Correspondence

Dr. Wynn

mwynn@wynn.mvipa.org

MORE ONLINE

ค Audio

Listen to Dr. Wynn read

this poem.

NPub.org/jo5qpc 


\section{Neurology}

\section{Hearing about your diagnosis while walking on the beach \\ Michael Wynn \\ Neurology 2019;93;80 \\ DOI 10.1212/WNL.0000000000007758}

This information is current as of July 8, 2019

\section{Updated Information \& Services}

\section{Subspecialty Collections}

Permissions \& Licensing

Reprints including high resolution figures, can be found at: http://n.neurology.org/content/93/2/80.full

This article, along with others on similar topics, appears in the following collection(s):

\section{All Clinical Neurology}

http://n.neurology.org/cgi/collection/all_clinical_neurology

Information about reproducing this article in parts (figures,tables) or in its entirety can be found online at:

http://www.neurology.org/about/about_the_journal\#permissions

Information about ordering reprints can be found online: http://n.neurology.org/subscribers/advertise

Neurology ${ }^{\circledR}$ is the official journal of the American Academy of Neurology. Published continuously since 1951, it is now a weekly with 48 issues per year. Copyright @ 2019 American Academy of Neurology. All rights reserved. Print ISSN: 0028-3878. Online ISSN: 1526-632X.

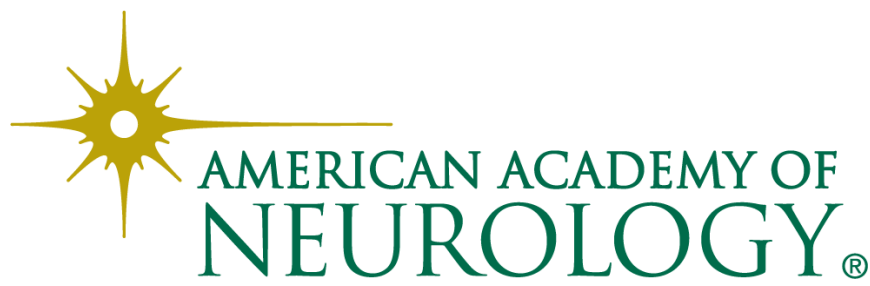

